\title{
Analytical Performance Analysis of Cross Flow Louvered Fin Automobile Radiator
}

\author{
Badgujar Pankaj $R^{l}$, Rangarajan $S^{2}$, Nagaraja S. $R^{3^{*}}$ \\ ${ }^{1,3}$ Department of Mechanical Engineering, Amrita School of Engineering, Bengaluru, Amrita Vishwa Vidyapeetham, India \\ ${ }^{2}$ Renault Nissan Technology and Business Centre India Pvt. Ltd. Ascendas IT Park, Mahindra World City, Chennai, Tamilnadu, India
}

\begin{abstract}
The objective of the present paper is to propose an analytical model for calculating performance parameter of a radiator having rectangular tube with louvered fins. The theoretical effectiveness, heat transfer rate, outlet temperatures of both air and coolant are determined using effectiveness-NTU method. The coolant and air side pressure drop is also calculated. The proposed procedure is validated with experimetal results available in the literature and the GT model. It is found that the maximum deviation in the heat transfer rate calculated from proposed model is $10.97 \%$, the coolant and air outlet temperatures is $2.75 \%$ and variation in pressure drop is about $3.29 \%$.
\end{abstract}

\section{Introduction}

Radiator is the main component of engine cooling system. It plays an important role in keeping the engine temperatures with prescribed limits by removing heat from the hot coolant fluid. The coolant fluid takes heat from engine cylinder jacket and this hot fluid flow through the radiator tubes and gets cooled by exchanging heat with air which flows over fins and tubes. The heat transfer rate is increased by increasing the surface area for heat transfer using fins. In most of the automobile radiators louvered fins with rectangular cross section are used. Louvered fins are more efficient than rectangular fins. It is easy to attach fins to the rectangular tube rather than circular or oval shape tube and hence most of the radiators use rectangular tubes.

Matthew Carl et al [1] have proposed study on heat transfer process in automobile radiator including the detailed explanation of correlations for radiator performance. A. Khot et al [2] have proposed study on various methods for radiator performance evaluation. In this paper LMTD, Effectiveness- NTU method and experimental method for evaluation of radiator performance are studied. They have concluded that the heat dissipation increase with increase in pressure drop and flow rate. P. S. Amrutkar and aaa [3] have validated the effectiveness-NTU method using simulations. They have used $\varepsilon$-NTU method for thermal analysis of a radiator. P. Mounika et al [4] have analysed the performance of an automobile radiator for air speeds in the range of $15 \mathrm{kmph}$ to $75 \mathrm{kmph}$. They have used ethylene glycol as coolant and concluded that even at higher speeds the given radiator with given number of fins attached to it works properly with slight compromise in decrease in efficiency of the fins used in the radiator. $\mathrm{E} \mathrm{Y} \mathrm{Ng} \mathrm{et} \mathrm{al} \mathrm{[5]} \mathrm{have} \mathrm{proposed} \mathrm{a} \mathrm{method} \mathrm{to} \mathrm{predict} \mathrm{the}$ heat transfer performance in car radiators. They have developed generalized analytical model accounting for airflow maldistribution. They have concluded that loss in engine cooling performance due to airflow maldistribution is relatively small when compared with the condition where airflow distribution is uniform with same total flow rate. R. Prakash et al [6] have proposed the radiator having two flat plates inside the tube which act as the nozzle. They have found that the nozzle effect provides additional cooling to the engine and hence the efficiency of the proposed radiator increased by $5.37 \%$ when comparing with existing radiators. Hiteshgiri et al [7] have found effectiveness, pressure drop and heat transfer rate of micro cross flow heat exchanger. They have found that for the same effectiveness, the heat transfer rate increases and the pressure drop decreases with rising working fluid temperature in the hot and the cold flow side. A. R. Esmaeili Sany et al [8] have studied radiator performance of passenger cars experimentally for wide range of operating conditions. They have found that heat transfer results from wind tunnel tests are $50 \%$ better than the actual conditions due to better air distribution. Vaisi. A et al [9] have studied the air-side heat transfer and pressure drop characteristics of flow over louvered fins in compact heat exchangers experimentally and concluded that the heat transfer rate tends to increase with an increasing inlet air velocity and also the performance of heat exchanger with louvered fins is affected by its geometrical parameters. Govindaraj. D [10] has used simulation tools for predicting cooling system performance. They have generated component performance characteristics through combined empirical and analytical methods in a consistent way thereby eliminating the discrepancies which would otherwise have occurred because of different testing methods. Solomon et al [11] have explained different geometric correlations for louvered fin radiator geometry. 


\subsection{Nomenclature}

\begin{tabular}{|c|c|c|}
\hline Parameters & Notation & Unit \\
\hline core height & $B_{H}$ & $\mathrm{~m}$ \\
\hline core width & $B_{W}$ & $\mathrm{~m}$ \\
\hline core thickness & $B_{t}$ & $\mathrm{~m}$ \\
\hline $\begin{array}{l}\text { Number of rows of tube in core } \\
\text { depth }\end{array}$ & $N_{r}$ & \\
\hline $\begin{array}{l}\text { Number of coolant tube in one } \\
\text { row }\end{array}$ & $N_{c t}$ & \\
\hline Number of profiles & $N_{p}$ & \\
\hline Number of fins & $N_{f}$ & \\
\hline Louver pitch & $L_{p}$ & $\mathrm{~m}$ \\
\hline Louver length & $L_{l}$ & $\mathrm{~m}$ \\
\hline Fin pitch & $\mathrm{F}_{\mathrm{p}}$ & $\mathrm{m}$ \\
\hline Fin end radius & $R_{f}$ & $\mathrm{~m}$ \\
\hline Fin thickness & $\mathrm{F}_{\mathrm{t}}$ & $\mathrm{m}$ \\
\hline Fin height & $\mathrm{F}_{\mathrm{h}}$ & $\mathrm{m}$ \\
\hline Angle of fin & $\alpha$ & degree \\
\hline coolant tube length & $Y_{l}$ & $\mathrm{~m}$ \\
\hline coolant tube cross section length & $Y_{\mathrm{cl}}$ & $\mathrm{m}$ \\
\hline coolant tube cross section width & $Y_{G W}$ & $\mathrm{~m}$ \\
\hline coolant tube thickness & $Y_{t}$ & $\mathrm{~m}$ \\
\hline coolant tube pitch & $\overline{Y p}$ & $\mathrm{~m}$ \\
\hline Coolant mass flow rate & $\mathrm{M}_{\mathrm{c}}$ & $\mathrm{Kg} / \mathrm{s}$ \\
\hline Air mass flow rate & $M_{a}$ & $\mathrm{~kg} / \mathrm{s}$ \\
\hline Specific heat capacity for coolant & $\mathrm{C}_{\mathrm{pc}}$ & $\mathrm{J} / \mathrm{Kg} . \mathrm{k}$ \\
\hline Specific heat capacity for air & $\mathrm{C}_{\mathrm{pa}}$ & $\mathrm{J} / \mathrm{Kg} \cdot \mathrm{k}$ \\
\hline Density of coolant & $\rho_{\text {coolant }}$ & $\mathrm{kg} / \mathrm{m}^{3}$ \\
\hline Density of air & $\rho_{\text {air }}$ & $\mathrm{kg} / \mathrm{m}^{3}$ \\
\hline Thermal conductivity of coolant & $K_{c}$ & $\mathrm{~W} / \mathrm{m} . \mathrm{k}$ \\
\hline Thermal conductivity of air & $K_{a}$ & $\mathrm{~W} / \mathrm{m} . \mathrm{k}$ \\
\hline Inlet temperature of coolant & $T_{h i}$ & $\mathrm{k}$ \\
\hline Outlet temperature of coolant & $T_{h o}$ & $\mathrm{k}$ \\
\hline Inlet temperature of air & $T_{c i}$ & $\mathrm{k}$ \\
\hline Outlet temperature of air & $T_{c o}$ & $\mathrm{k}$ \\
\hline Kinematic viscosity of coolant & $\vartheta_{\text {coolant }}$ & $\mathrm{m} / \mathrm{s}$ \\
\hline Kinematic viscosity of air & $\vartheta_{\text {air }}$ & $\mathrm{m} / \mathrm{s}$ \\
\hline Prandtl number for coolant & $P_{r c}$ & \\
\hline Prandtl number for Air & $P_{r a}$ & \\
\hline Pressure drop & $\Delta P$ & \\
\hline Hydraulic diameter coolant side & $D_{h o}$ & \\
\hline Hydraulic diameter air side & $D_{h a}$ & \\
\hline
\end{tabular}

\section{Model Development}

Modern automobiles use radiators with multi-louvered fins with rectangular tubes. This increases the air-side heat transfer performance by more than $60 \%$ when compared with the traditional plate fin heat exchangers. The louvered fins provide more surface area for heat transfer. The proposed model uses rectangular tube with louvered fins. The performance of the model is compared with experimental [9] and GT model results. The geometric, Reynolds and Nusselt number correlations from reference [11], effectiveness-NTU correlations [12] and pressure drop correlations [13] are used. These correlations are given below. Figure 1 and 2 show the geometry of a typical louvered fin radiator.

\section{A. Geometry correlations}

1. Fin length -

$$
F_{l=} \pi R_{f}+\frac{F_{h}-2 R_{f}}{\cos \alpha_{f}}
$$

2. Radiator core frontal area - $A f_{r, r=} B_{H} B_{W}$

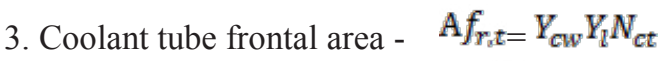

4. Fin frontal heat transfer area- $A f_{r, f=} F_{t} F_{l} N_{f} Y_{l} N_{p}$

5. Fin heat transfer area-

$$
A_{f=} 2 B_{t} F_{l} N_{f} Y_{l} N_{p}
$$

6. Total heat transfer area on air side:

$$
A_{a}=A_{f}+2 N_{c t} Y_{l} N_{r}\left[\left(Y_{c l}-2 R_{t}\right)+\left(2 \pi R_{t}\right)\right]
$$

7. Total heat transfer area on the coolant side:

$$
A_{c}=\left[2 \pi\left(R_{t}-Y_{t}\right)+2\left(Y_{c l}-2 R_{t}\right)\right] Y_{l} N_{c t} N_{r}
$$

8. Effective fin length: $\quad \mathrm{L}=\frac{\mathrm{F}_{\mathrm{h}}}{2}$

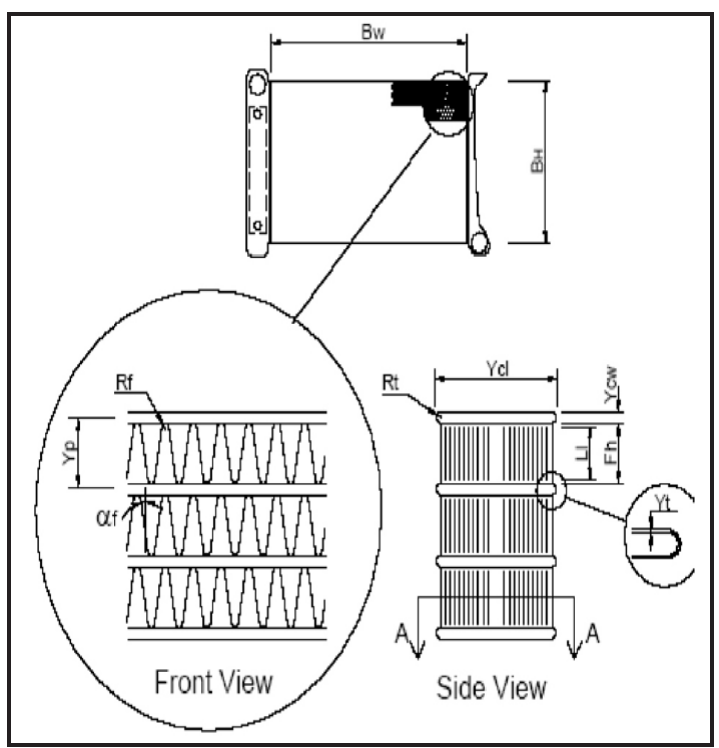

Fig.1. Geometry of Louvered Fin Radiator 


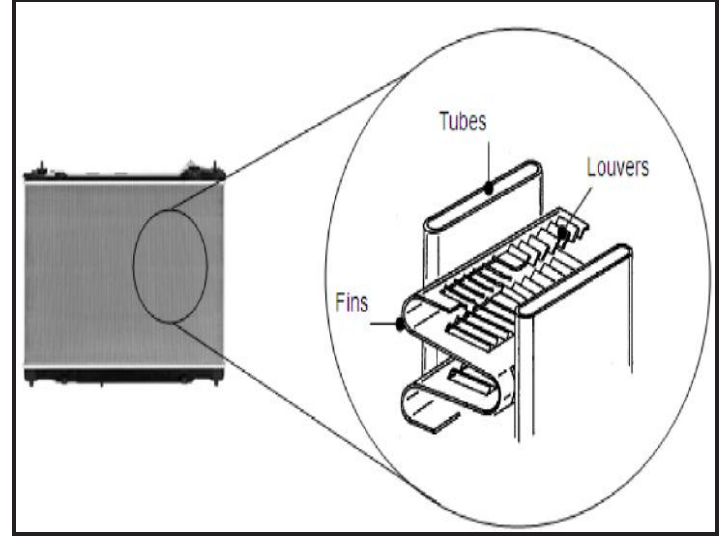

Fig.2. Tube and Louvered fin geometry description

\section{B. Reynolds and Nusselt number correlations}

1. Reynolds number for coolant:

$$
R c=\frac{V_{\text {coolant }} D_{\text {hy }}}{\vartheta_{\text {coolant }}}
$$

2. Reynolds number for Air

$$
R a=\frac{V_{\text {air }} L_{p}}{\vartheta_{\text {air }}}
$$

3. Nusselt number for air -

$$
N_{u a}=0.664 R_{a}^{0.5} P r_{a}^{0.3333}
$$

4. Nusselt number for coolant-

For Different flow regime, the following equations were used for Nusselt number

i. Laminar flow $(2300<\mathrm{Rc})$

Hansen equation:

$$
N_{u c}=3.66+\frac{0.0668\left(\frac{D_{h c}}{Y_{l}}\right) R_{c} P_{r c}}{1+0.04\left[\left(\frac{D_{h c}}{Y_{l}}\right) P_{r c}\right]^{0.666}}
$$

ii. Nusselt number for coolant Turbulent flow (Rc>10000)

Petukhov equation:

$$
N_{u c}=\frac{\frac{f_{R_{c}} P_{r c}}{1.07+12.7 x\left(\frac{f}{g}\left(P_{r c}^{0.666}-1\right)\right)^{0.5}}}{1.00}
$$

iii. Nusselt number for coolant Transition Flow

$$
\text { ( } 10000 \geq R c \geq 2300 \text { ) }
$$

Gnielinski equation:

Where,

$$
N_{u c}=\frac{\frac{f}{8}\left(R_{c}-1000\right) P_{r c}}{1+12.7\left(\frac{f}{g}\right)^{0.5}\left(P_{r c}^{0.666}-1\right]}
$$

$$
\text { Friction factor: } \quad f=\left[0.79\left(\ln \left(R_{c}\right)\right)-1.64\right]^{-2}
$$

\section{Effectiveness-NTU Correlations}

1. Heat transfer coefficient:

$$
h=\frac{N u k}{D_{h y}}
$$

2. Overall heat transfer coefficient:

In a radiator the overall heat transfer coefficient depends on the convective heat transfer coefficient on air and coolant side, wall conduction and the fouling factors on air and coolant side.

$$
U A_{f r s} r=\frac{1}{\frac{1}{\eta_{o h_{\text {air }} A_{a}}}+\frac{1}{h_{\text {coolant }} A_{c}}}
$$

3. Number of transfer units:

$$
N T U=\frac{U A_{f r, r}}{C_{\min }}
$$

4. Effectiveness:

$$
\epsilon=1-\exp \left\{\left(\frac{1}{C r} N T U^{0.22}\right)\left(\exp ^{-C r N T U^{0.78}}-1\right)\right\}
$$

5. Maximum heat transfer rate:

$$
Q_{\max }=C_{\min }\left(T_{h i}-T_{c i}\right)
$$

6. Actual heat transfer rate:

$$
Q_{\text {act }}=\epsilon Q_{\max }
$$

7. Coolant outlet temperature:

$$
T_{\text {ho }}=T_{\text {hi }}-\frac{Q_{\text {act }}}{C_{\text {coolant }}}
$$

8. Air outlet temperature:

$$
T_{c o}=T_{c i}+\frac{Q_{\text {act }}}{C_{\text {air }}}
$$

\section{Fin Efficiency corrélations}

1. Fin Efficiency :

$$
\eta_{\text {fin }}=\frac{\tanh \left(m L_{c}\right)}{m L_{r}}
$$

Where,

$$
m=\left(\frac{h_{a} F_{p}}{K_{f} A_{c}}\right)^{0.5}
$$

2. Overall Efficiency:

In radiator both the finned and un-finned surfaces contribute to the overall heat transfer. The overall surface efficiency is defined for the composite structure consisting of both the fins and base structure and it can be calculated as

$\eta_{\text {overall }}=1-\frac{N_{\text {fin }} A_{f}}{A_{\text {fin base }}}\left(1-\eta_{\text {fin }}\right)$

E. Pressure drop corrélations

1. Coolant side pressure drop

$$
\Delta P_{\text {coolant }}=\frac{L_{\text {tubs }} N_{\text {pass }} G^{2}}{2 D_{h y} \rho_{\text {coolant }}} 4 f
$$

2. Air side pressure drop

$$
\begin{aligned}
& \quad \Delta P_{\text {air }}=\frac{G^{2}}{2 \rho_{i}}\left(\left(1-\sigma_{i}^{2}+k_{c}\right)+\frac{4 f L}{D_{h y}}\left(\frac{\rho_{i}}{\rho_{m}}\right)\right. \\
& +2\left(\frac{\rho_{i}}{\rho_{e}} 1\right)- \\
& \left.\sigma_{e}^{2}-k_{e}\right)\left(\frac{\rho_{i}}{\rho_{e}}\right.
\end{aligned}
$$

Where,

Mass velocity $G=\rho v$

$k_{e}=(1-\sigma)^{2}$

$k_{c}=0.42\left(1-\sigma^{2}\right)^{2}$

$k_{c}$ and $k_{e}$ are the contraction and expansion coefficients respectively.

$\rho_{i}, \rho_{\text {mand }} \rho_{e}$ are inlet density, mean density and outlet density respectively.

$$
\sigma=\frac{\text { Minimum flow area }}{\text { Frontal area }}
$$

passage contraction ratio. 


\subsection{Proposed Analytical Model}

An analytical model is proposed to find the effectiveness of louvered fin radiator. The flow chart shown in figure 3 describe the procedure for the calculation of effectiveness, heat transfer rate, outlet temperature for both coolant and air for the proposed analytical model. The flow chart describes detailed step by step calculation procedure. The inputs to the calculation are radiator geometry, mass flow rate and velocity of coolant and air, inlet coolant and air temperature as well as properties of coolant and air. From this input Reynolds number is calculated and this helps in deciding the type of flow (laminar, transition or turbulent). Based on the type of flow, equation for calculating the Nusselt number is selected. After calculating the heat transfer coefficient and fin efficiency, the overall heat transfer coefficient and the number of transfer units (NTU) are calculated. Effectiveness correlation is used for the calculation of effectiveness by using NTU. Maximum heat transfer rate is calculated from the input temperatures and minimum heat capacity. By using this maximum heat transfer rate and effectiveness, actual heat transfer rate, outlet temperature of the coolant and air are calculated. After calculating friction factor, mass velocity and hydraulic diameter, pressure drop on coolant side and air side are calculated.

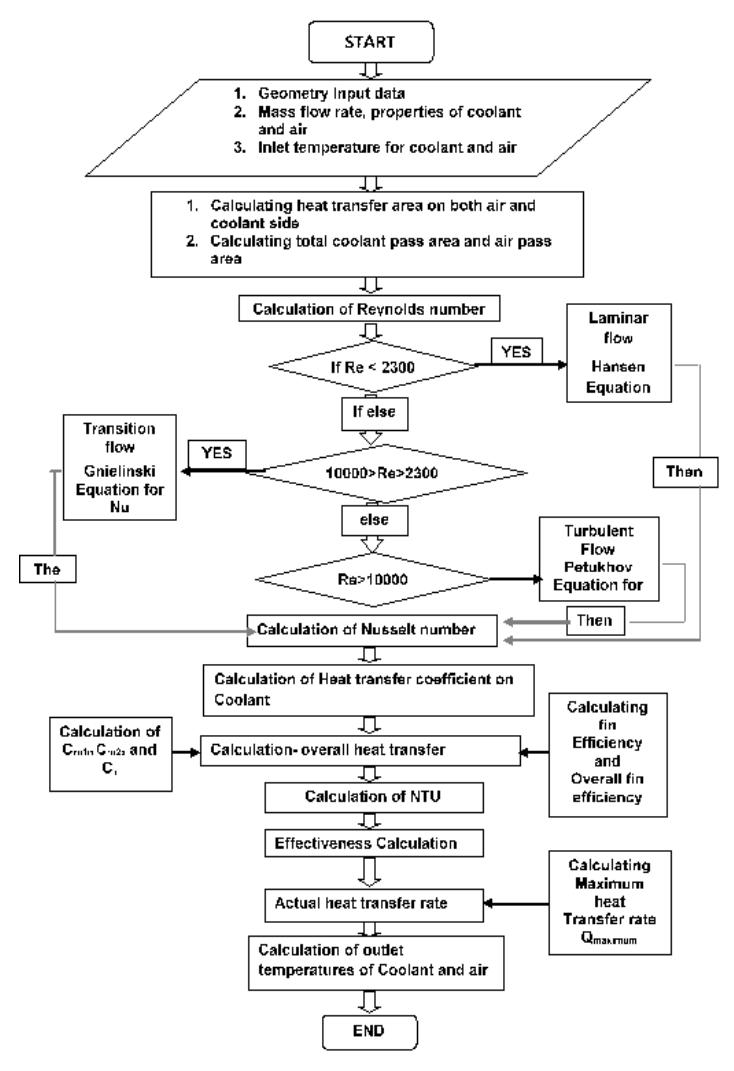

Fig.3. Process Flow Chart

\section{Results and Analysis}

The analytical model proposed is validated by comparing the results obtained for the model with those available in literature. Two models are used for this purpose, one experimental results of rectangular tube louvered fin radiator [9] and GT model radiator.

The input conditions for the analytical model are same as given in the reference [9]. Table 1 shows input conditions for different trials. The geometric parameters used are same as that given in the reference [9]. The comparison between the experimental [9] and the analytical results using the proposed procedure are shown in Table 2. It is observed that the calculated results obtained from proposed model closely agree with experimental results. The maximum \% error in the heat transfer rate is 3.78. Figures 4 and 5 show the variation of coolant and air outlet temperatures for different trails. It can be observed that the deviation in outlet temperature of coolant is $\pm 1 \%$ and that of outlet temperature of air is $\pm 2 \%$. The pressure drop calculations are not shown this model since in the experiments carried by Vaisi. A et al [9] have not measured the pressure drop.

Table 1. Input conditions for Coolant and air [9]

\begin{tabular}{|l|c|c|c|c|c|c|}
\hline \multirow{2}{*}{ Parameters } & \multirow{2}{*}{ Unit } & \multicolumn{5}{|c|}{ Testing trials } \\
\cline { 3 - 7 } & & I & II & III & IV & V \\
\hline $\begin{array}{l}\text { Coolant mass flow } \\
\text { rate }\end{array}$ & $\mathrm{kg} / \mathrm{s}$ & 2 & 2 & 2 & 2 & 2 \\
\hline Air mass flow rate & $\mathrm{kg} / \mathrm{s}$ & 1.124 & 1.372 & 1.627 & 1.956 & 2.143 \\
\hline $\begin{array}{l}\text { Coolant inlet } \\
\text { temperature }\end{array}$ & ${ }^{\circ} \mathrm{c}$ & 80 & 80 & 80 & 80 & 80 \\
\hline $\begin{array}{l}\text { Air inlet } \\
\text { temperature }\end{array}$ & ${ }^{\circ} \mathrm{c}$ & 20.3 & 20.3 & 20.3 & 20.3 & 20.3 \\
\hline Air velocity & $\mathrm{m} / \mathrm{s}$ & 5.58 & 6.81 & 8.09 & 9.71 & 10.64 \\
\hline
\end{tabular}

Table 2. Comparison between analytical and experimental results

\begin{tabular}{|c|c|c|c|c|c|c|c|}
\hline Trials & \multirow{2}{*}{$\begin{array}{c}\text { Heat Transfer } \\
\text { rate }\end{array}$} & \multirow{2}{*}{$\begin{array}{c}\text { Error in } \\
\text { Heat } \\
\text { transfer } \\
\text { rate }\end{array}$} & $\begin{array}{c}\text { Outlet } \\
\text { temperature } \\
\text { of water }\end{array}$ & \multicolumn{2}{|c|}{$\begin{array}{c}\text { Outlet } \\
\text { temperature } \\
\text { of air }\end{array}$} \\
\hline & $\begin{array}{c}\text { Analyt } \\
\text { ical }\end{array}$ & Exp & $\begin{array}{c}\text { Analyt } \\
\text { ical }\end{array}$ & Exp & $\begin{array}{c}\text { Analyt } \\
\text { ical }\end{array}$ \\
\hline Unit & $\mathrm{kw}$ & $\mathrm{kw}$ & $\%$ & ${ }^{\circ} \mathrm{C}$ & ${ }^{\circ} \mathrm{C}$ & ${ }^{\circ} \mathrm{C}$ & ${ }^{\circ} \mathrm{C}$ \\
\hline I & 43.28 & 42.76 & -1.19 & 73.99 & 73.75 & 54.28 & 55.76 \\
\hline II & 47.40 & 47.49 & 0.19 & 73.29 & 73.15 & 51.29 & 52.13 \\
\hline III & 50.87 & 50.96 & 0.17 & 72.87 & 72.65 & 48.61 & 49.05 \\
\hline IV & 54.42 & 56.28 & 3.43 & 72.24 & 72.14 & 45.70 & 45.92 \\
\hline V & 56.13 & 58.25 & 3.78 & 71.53 & 71.89 & 44.23 & 44.42 \\
\hline
\end{tabular}


Table 3. Input conditions for Coolant and air from GT Model

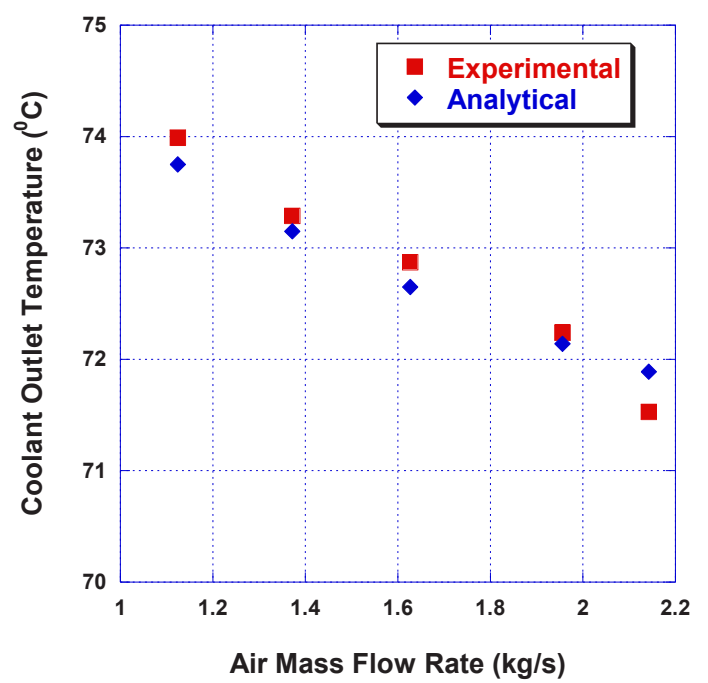

Fig. 4. Comparison between analytical and experimental coolant outlet temperature

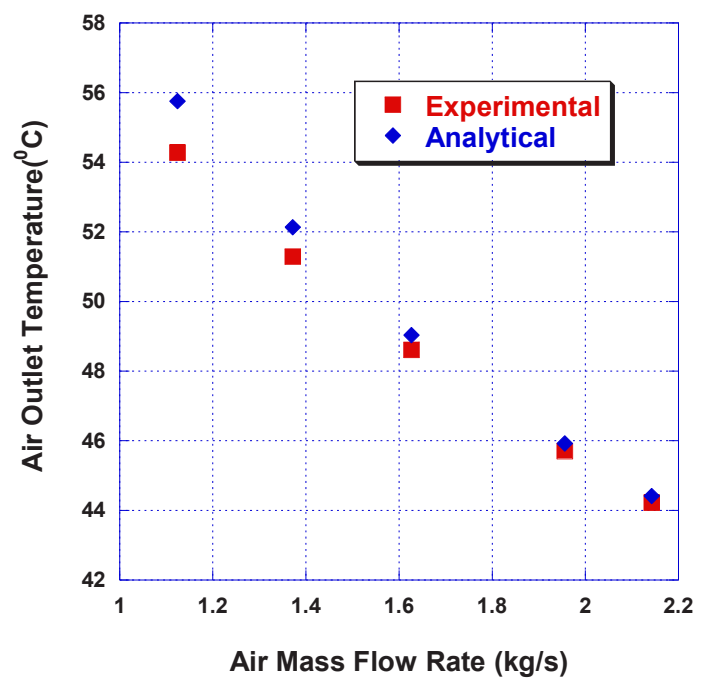

Fig. 5. Comparison between analytical and experimental Air outlet temperature

The proposed analytical model is also validated using the results for GT model. GT model is a cross flow rectangular tube louvered fin radiator used by Renault Nissan. This model also has correlations for pressure drop calculations. Table 3 shows the input parameters used for these calculations. The geometric parameters used are the same as those used in GT model. The comparison between the GT model and proposed model are as shown in table 4 . It can be observed that the maximum error in heat transfer is $10.97 \%$ and in pressure drop is $3.29 \%$.

\begin{tabular}{|l|c|c|c|c|c|c|}
\hline \multirow{2}{*}{ Parameters } & \multirow{2}{*}{ Unit } & \multicolumn{5}{|c|}{ TRIALS } \\
\cline { 3 - 7 } & & $\mathrm{I}$ & $\mathrm{II}$ & $\mathrm{III}$ & $\mathrm{IV}$ & $\mathrm{V}$ \\
\hline $\begin{array}{l}\text { Coolant } \\
\text { mass flow } \\
\text { rate }\end{array}$ & $\mathrm{kg} / \mathrm{s}$ & 0.44 & 0.88 & 1.32 & 1.76 & 2.2 \\
\hline $\begin{array}{l}\text { Air mass } \\
\text { flow rate }\end{array}$ & $\mathrm{kg} / \mathrm{s}$ & 0.29 & 0.29 & 0.29 & 0.29 & 0.29 \\
\hline $\begin{array}{l}\text { Inlet } \\
\text { temperature } \\
\text { of Coolant }\end{array}$ & ${ }^{\circ} \mathrm{c}$ & 95 & 95 & 95 & 95 & 95 \\
\hline $\begin{array}{l}\text { Inlet } \\
\text { temperature } \\
\text { of Air }\end{array}$ & ${ }^{\circ} \mathrm{c}$ & 25 & 25 & 25 & 25 & 25 \\
\hline
\end{tabular}

Table 4. Comparison between GT model and analytical results

\begin{tabular}{|c|c|c|c|c|c|c|}
\hline \multirow{2}{*}{$\begin{array}{c}\text { Tr } \\
\text { ial }\end{array}$} & \multicolumn{2}{|c|}{$\begin{array}{c}\text { Pressure drop } \\
\text { coolant side }\end{array}$} & \multirow{2}{*}{$\begin{array}{c}\text { Error } \\
\text { in }\end{array}$} & \multicolumn{2}{|c|}{$\begin{array}{c}\text { Heat transfer } \\
\text { rate (Q) }\end{array}$} & $\begin{array}{c}\text { Error } \\
\text { in }\end{array}$ \\
& Exp & $\begin{array}{c}\text { Analyt } \\
\text { ical }\end{array}$ & \multirow{2}{*}{$\Delta P$} & $\begin{array}{c}\text { Analyt } \\
\text { ical }\end{array}$ & Exp & Q \\
\hline & bar & bar & $\%$ & KW & Kw & $\%$ \\
\hline I & 0.0095 & 0.0093 & 3.07 & 12.27 & 11.06 & 10.97 \\
\hline II & 0.0282 & 0.0286 & -1.32 & 15.02 & 13.95 & 7.68 \\
\hline III & 0.0565 & 0.0560 & 0.47 & 16.27 & 15.42 & 5.51 \\
\hline IV & 0.0938 & 0.0908 & 3.29 & 16.97 & 16.32 & 3.99 \\
\hline V & 0.1480 & 0.1434 & 3.18 & 17.43 & 16.94 & 2.87 \\
\hline
\end{tabular}

\section{Conclusions}

Analytical model for radiator having rectangular tube with louvered fin is developed. Analytical correlations are validated with the two different models of radiator and results agree closely. Heat transfer rate and pressure drop results obtained from the analytical model compared with the GT model results. The maximum deviation in heat transfer is $10.97 \%$ and that in pressure drop is $3.29 \%$. The analytical model developed also predicts the outlet temperatures of both coolant and air. The analytical model results are also compared with the experimental results. The maximum difference between the experimental and analytical values for heat transfer rate is $3.78 \%$. The maximum deviation between experimental and analytical values of coolant outlet temperature is $1 \%$ and that of air outlet temperature is $2.75 \%$. The analytical model developed is capable to predicting the radiator performance i.e. heat transfer rate, 
coolant and air outlet temperatures, pressure drop of both coolant side as well as air side.

We would like to acknowledge the support of Renault Nissan Technology and Business Centre India Pvt. Ltd. for permitting to carry out this work.

\section{References}

1. Matthew Carl, Dana Guy, Brett Leyendecker, Austin Miller, and Xuejun Fan, ASEE Gulf Southwest Annual Conference (2012)

2. A. R. Khot, D.G. Thombar, S. P. Gaikwad, A. S. Adadande, IOSR-JMCE, 07, (2014)

3. P. S. Amrutkar, S. R. Patil, IOSR-JMCE, (2005)

4. P. Mounika, Rajesh K Sharma, P. S. Kishore, IJRMEE, 3, (2016)

5. $\mathrm{E} \mathrm{Y} \mathrm{Ng}, \mathrm{P} \mathrm{W}$ Johnson, $\mathrm{S}$ Watkins, Proc. IMechE, Part D: J. Automobile Engineering, 219 (2005)

6. R. Prakash, M. Selvam, A. Alagu Pandian, S. Palani and K. A. Harish, Indian Journal of Science and Technology, 9, (2016)

7. Hiteshgiri Goswami and Jiten Makadia, International Journal of Engineering Research \& Technology, 2, (2013)

8. A. R. Esmaeili Sany, M. H. Saidi, J. Neyestani, The Journal of Engine Research, 18, (2010)

9. Vaisi, A, M. Esmaeilpour, and H. Taherian, Applied Thermal Engineering, 31, (2011)

10. Govindaraj. D., No. 2011-01-2185, SAE Technical Paper, (2011)

11. Solomon, Samson, No. 2013-01-2810, SAE Technical Paper, (2013)

12. Kothandaraman, C. P., and S. Subramanyam, Heat and Mass Transfer Data Book (2014)

13. Kakac, Sadik, HongtanLiu, and Anchasa Pramuanjaroenkij Heat exchangers: selection, rating, and thermal design. CRC press, (2012) 